УДК: 330. 341.1: (331.101.262:37.013/014)

\title{
ЯКІСТЬ СИСТЕМИ ОСВІТИ ЯК ОСНОВА ІННОВАЦІЙНОЇ ЕКОНОМІКИ
}

\author{
Бабенко В.А., ст. викладач (НУ «ОЮА»)
} освіта .

Сучасна економіка є економікою знань, де головним економічним ресурсом виступає

Освіта є важливою складовою при формуванні національної інноваційної економіки.

Стаття присвячена дослідженню теоретичних та практичних аспектів якості системи освіти як основи формування національної інноваційної економіки.

Метою даного дослідження є оџінка якості системи освіти на всіх ї̈ рівнях.

Ключові слова: інновацї̈, інноваційна економіка, освіта, якість системи освіти.

\section{КАЧЕСТВО СИСТЕМЫ ОБРАЗОВАНИЯ КАК ОСНОВА ИННОВАЦИОННОЙ ЭКОНОМИКИ}

\section{Бабенко В.А., ст. преподаватель (НУ «ОЮА»)}

Современная экономика является экономикой знаний, где основным экономическим ресурсом выступает образование.

Образование является важной составляющей при формировании нащиональной инновачионной экономики.

Статья посвящена исследованию теоретических и практических аспектов качества системы образования как основы формирования национальной инновационной экономики.

Целью данного исследования является оценка качества системы образования на всех её уровнях.

Ключевые слова: инновации, инновационная экономика, образование, качество системы образования.

\section{THE EDUCATIONAL SYSTEM QUALITY AS THE BASE OF THE INNOVATIVE ECONOMY}

\section{Babenko V.A., senior teacher (National University "Odessa Academy of Law»)}

Modern economy is the knowledge based economy. Now the main economic resource is the education. The education is the important component in the formation of the national innovative economy.

Without development of the educational system the Ukrainian economy cannot move to the innovative model.

The article is devoted the theoretical and practical aspects of the educational system quality with the purpose of the formation the national innovative economy.

The target of this research is the appraisal of the educational system quality in all its levels.

It was emphasized that the primary concern in the formation of the national innovative economy should become improvement of secondary and higher education, development of continuous education and life-long education on innovative basis.

Keywords: innovation, innovative economy, education, educational system quality.

Постановка проблеми. Інновації динаміка все більше синхронізується 3 виступають основним ресурсом та рушієм інноваційною, що свідчить про виключну роль сучасного соціально-економічного поступу. інновацій у досягненні високих темпів Починаючи $з$ 70-х років XX ст., економічна економічного зростання.

(C) Бабаченко B.A.

Вісник економіки транспорту і промисловості № 51, 2015 
Якщо для етапу індустріального розвитку характерним $\epsilon$ лідерство фактору капіталу, то для сучасного, постіндустріального, наукового знання. Сьогодні саме знання стає основним джерелом розвитку та багатства як для окремих людей, підприємств, регіонів, так і для країни в цілому [1].

За статистикою ЮНЕСКО, у двадцятьох країнах, де сконцентровано 95\% наукового потенціал планети, подушений НД щорічно зростає на 200 дол., у всіх інших країнах, де працює тільки 5\% учених світу, щорічне зростання прибутків становить усього 10 дол. [2,с.36].

На думку академіка НАН України А. Чухна, головним чинником інноваційного розвитку $\epsilon$ наука, яка створює нові зразки техніки й технології, та освіта, що забезпечує загальнокультурну i професійну підготовку людей, здатних і працювати з новою технікою, і управляти їі функціонуванням [3].

Освіта створює базис для всебічної інтелектуалізації економіки, визначає потенціал та вектор науково-технічного прогресу, а отже, є найважливішим чинником інноваційної економіки, отже для переходу економіки України до інноваційної моделі розвитку необхідно приділити найсерйознішу увагу якості системи освіти.

Аналіз останніх досліджень та публікацій. Вивчаючи зв'язок між освітою на економічним зростанням у 25 великих країнах світу, американський фахівець у галузі економічної історії Істерлін обгрунтував висновок про те, що сучасне економічне зростання зумовлене переважно потенційними знаннями населення i його мотиваціями, в основі яких лежить освіта [4, с.107].

Співробітники

Нідерландського інституту економіки розрахували, що в 23 різних за рівнем економічного розвитку країнах кожні 1,038\% приросту в структурі робочої сили працівників 3 вищою освітою і $0,65 \%$ приросту працівників із середньою освітою призводили до збільшення на $1 \%$ НД.

За даними Т.Шульца, розвиток системи освіти в США за період 1929-1957pp. забезпечив приріст НД на 21\% при нормі віддачі $11 \%$ [5, с.121].

Г.Беккер першим виконав статистично коректний розрахунок економічної ефективності освіти. Інвестиції в людський капітал не тільки сприяють збільшенню доходів індивіда, а й зумовлюють підвищення продуктивності праці. Наприклад, освіта, окрім формування професійних знань і навичок, розвиває також підприємницькі таланти, зменшує опір нововведенням, спрощує сприйняття змін; підготовка й підвищення кваліфікації на виробництві (накопичення виробничого досвіду) сприяє швидкому й безболісному переходу на нові технології [6].

Швидкий розвиток науки i техніки вносить суттєві корективи у освітній процес. Сьогодні доведено, що у сфері науки i проектування так званий період напіврозпаду знань (за термінологією А.Шапіро) становить приблизно п'ять років. Причому, за даними П.Книхта [6], розрізняються знання 3 тривалим та коротким періодами напіврозпаду. До перших належать академічна, теоретична освіта, що одночасно $є$ базою для придбання багатьох видів знання 3 коротким періодом напіврозпаду. Час формування таких знань $є$ тривалим, період окупності - довгим, але вони дають високий соціальний ефект.

Проблеми освіти досліджували в різні часи багатьох зарубіжних та вітчизняних науковців, зокрема: Й.М.Бескид, Ю.Я.Бобало, Я.Я.Болюбаш, І.О.Вакарчук, Ю.М.Вітренко, Є.Г.Сфімов, М.З.Згуровський, Р.Ю.Кігель, К.В.Корсак, В.Г.Кремінь, В.І.Куценко, М.Я.Матвєєв, В.М.Новіков, Ю.М.Олексєєв, В.А.Яблонський, Т.Шульц та ін. Проблемі якості освіти присвячені праці таких вчених, як Н.В.Москаленко, І.О.Потай, І.А.Шайдур та iн.

Виділення невирішених частин загальної проблеми. Сучасна система освіти, створюючи фундамент інноваційної економіки, i сама має базуватися на інноваційних засадах, постійно розвиватися i вдосконалюватися.

Отже, вимагає подальшого вивчення якість системи освіти в контексті формування інноваційної економіки.

Метою статmі є дослідження якості системи освіти як основи розвитку інноваційної економіки.

Виклад основного матеріалу дослідження. Однією із стратегічних цілей розвитку ЄС до 2011p., визначених на Саміті Свропейської Ради у Лісабоні в березні 2003p., було визначено підготовку до

Вісник економіки транспорту і промисловості № 51, 2015 
переходу до цифрової економіки, що грунтується на високому рівні освіти.

Перший Форум 3 економіки знань, що відбувся у Парижі у лютому 2002p. під назвою «Розбудова економіки знань - можливості та виклики для країн-претендентів на вступ до ЄС», фокусувався на підходах до формування політики 3 чотирьох складових економіки знань: економічного та інституційного режиму, освіченого та кваліфікованого населення, інформаційної інфраструктури та національної інноваційної системи. На Саміті Європейської Ради у Барселоні (березень 2005p.) європейські уряди зобов'язалися активізувати наукові дослідження та інновації шляхом збільшення видатків на ці цілі. Передбачалася реструктуризація європейського наукового простору у дійсно конкурентний, мобільний дослідницький ринок, реалізація Інноваційної програми для Європейської спільноти, що сприятиме вільному обігу технологій поряд 3 вільним обігом товарів, і на цій основі просування та більш ефективне використання інновацій.

Другий Форум 3 економіки знань у Гельсінкі в березні 2006р. був присвячений впровадженню економіки знань у країнах Центральної та Східної Свропи. Представники всіх запрошених країн-кандидатів, а також Росії, України та Туреччини у своїх доповідях демонстрували результати впроваджених програм i заходів по одній 3 чотирьох складових стратегії. За результатами досліджень була доведена необхідність врахування п’ятої складової - держави як ініціатора та координатора впровадження економіки знань в усі сфери життєдіяльності країни.

Невід'ємною основою впровадження економіки знань виступає належний рівень розвитку національної системи освіти.

Основними

конкурентоспроможності національних систем освіти, за оцінками Всесвітнього економічного форуму, є такі: якість освітньої системи; якість математичної освіти; якість навчальних закладів 3 підготовки управлінців; сприйнятливість наукових інститутів до інноваційних змін; розповсюдженість систем перепідготовки персоналу; наявність професійних управлінців; якість науководослідних інститутів; сприйнятливість науковців та інженерів до інноваційних змін $[7$, c.44].
Як бачимо, центральною проблемою розвитку освіти виступає забезпечення іiі якості. Саме на це звертає увагу більшість науковців і практиків, що працюють в сфері освіти.

Якість розглядається не тільки як результат діяльності, а і як можливості його досягнення у вигляді внутрішнього потенціалу та зовнішніх умов, а також як процес формування характеристик [8].

Якість освіти в узагальненому визначенні - це комплекс показників компетентності і професійної свідомості, що характеризують здатність особи здійснювати фахову діяльність відповідно до вимог сучасного етапу розвитку економіки, на визначеному рівні ефективності та професійного успіху, із розумінням соціальної відповідальності за результатами фахової діяльності.

Проблема якості освіти полягає не тільки в забезпеченні певного обсягу знань, скільки в їхній структурі, вмінні використовувати набуті знання для вирішення професійних задач, здатності постійно навчатися, творчо мислити.

Слід зауважити, що в перехідній економіці існує два протилежних погляди стосовно якості освіти. Представники сфери освіти вважають, що низька затребуваність економікою науково-інтелектуального ресурсу, утвореного системою освіти й, особливо, університетським сектором, зумовлена незадовільними темпами інноваційної модернізації економіки. Навпаки, підприємці звинувачують систему освіти в «освітньому сепаратизмі», замкнутості на цілях саморозвитку, наслідками якого стають неприйнятна якість освітніх послуг i наукового продукту, недовиробництво наукового й інтелектуального потенціалу, здатного забезпечити інноваційну компоненту розвитку.

Фактично проблема якості освіти зумовлена трансформацією індустріального суспільства в постіндустріальне, еволюцією ролі людини в економіці, становленням i розвитком людського капіталу. Вона вимагає перегляду економічних відносин у сфері освіти.

Якість освіти забезпечується такими чинниками, як: якість учнів та якість викладацького складу, якість освітніх стандартів, якість матеріально-технічної та 
інформаційно-методичної бази освітнього процесу, якість технології освіти, творчість та ефективність педагогічної та виховної роботи, якість управління, організації, контролю освітнього процесу.

Оцінити стан якості освіти дуже складно, система традиційних показників, що вимірюють кількість випускників чи успішність навчання, тут, на жаль, не придатна. Зрозуміло, що необхідний новий методологічний апарат, який треба якнайшвидше розробити та застосувати на практиці.

Спробуємо оцінити якість освіти в Україні за наявними даними.

Аналіз місця України у рейтингу конкурентоспроможності в контексті відповідності освітньої системі вимогам інноваційних змін свідчить про значне відставання за всіма показниками від розвинених країн. Зокрема, за рівнем сприйнятливості до інновацій науковців та інженерів спостерігається відставання України (4,6 бали порівняно з 6,0 у Фінляндії; 5,8 - у США; 6,1 - у Сінгапурі). Щодо розвиненості систем навчання персоналу, що $\epsilon$ основою формування системи безперервної освіти, то бальна оцінка України за цією складовою майже вдвічі менша порівняно 3 країнами-лідерами у рейтингу конкурентоспроможності (Фінляндією, США, Швецією, Сінгапуром, Німеччиною) [7, с.44].

Відставання якості української системи освіти спостерігається на всіх рівнях.

На рівні загальної середньої освіти серйозне занепокоєння викликає той факт, що в Україні $\epsilon$ низькою якість математичної $\mathrm{i}$ природничої освіти: за міжнародним дослідженням TIMMS, яке вперше було проведене у 2007 р., з'ясувалося, що за рівнем успішності (за міжнародними тестами перевірялися учні 4-го та 8-го класів) Україна поступається Росії, Казахстану, Вірменії, країнам Балтії. Поглиблена освіта 3 фізики та математики взагалі зникла 3 бюджетного фінансування. Отже, випускники українських шкіл не мають належної підготовки для продовження освіти на природничих факультетах університетів або у вищих технічних навчальних закладах, в той час як саме такі напрями підготовки закладають базис науково-технічного прогресу. Фактично ми втрачаємо наш інтелектуальний потенціал вже на перших кроках його формування.
За даними дослідження Фонду «Демократичні ініціативи» ім. І.Кучеріва, $70,5 \%$ респондентів оцінюють якість вищої освіти в Україні як низьку та середню. Результати соціологічного опитування, проведеного Інститутом економіки та прогнозування НАН України, свідчать: понад $70 \%$ майбутніх фахівців в університетах опановують певну сукупність знань, можуть їх шаблонно застосовувати, але не здатні вирішувати незнайомі для них завдання; $20 \%$ випускників українських вишів дуже погано орієнтуються в обраних професія через власну недбалість і небажання вчитися; 10\% це випускники, які добре оволоділи методом самонавчання i самовдосконалення. Навіть якщо припустити, що ці останні $10 \%$ фахівців зможуть реалізувати себе в сфері НДДКР, віддача вищої освіти в Україні $є$ дуже низькою.

Суттєві прогалини спостерігаються в організації післядипломної освіти, яка мала б забезпечувати фахове удосконалення, поглиблення, оновлення професійних знань, умінь і навичок. Статистика свідчить, що в Україні в середньому на чотири підприємства підвищує кваліфікацію лише один працівник. В той час,як в сфері НДДКР (як було вказано вище) період напіврозпаду знань становить приблизно п'ять років, працівники в Україні підвищують кваліфікацію в середньому раз на 13-15 років (у розвинених країнах - раз на 3-5 років) [9].

Зростаючі темпи економічних знань $\mathrm{i}$ гнучкість ринку праці призводять до необхідності зміни роботи і навіть професії, що вимагає реалізації концепції безперервної освіти (освіти впродовж життя). За цим рівнем системи освіти Україна посідає 23-є місце в рейтингу серед 25 країн.

Навіть ці окремі показники свідчать про наявність серйозних прогалин у якості освіти в нашій державі.

Висновки даного дослідження $i$ перспективи подальших робіт у вказаному напрямі. На думку автора, якість освіти, насамперед, гальмують наступні проблеми.

Дотепер не розроблені параметри, необхідні для оцінки ролі освіти у формуванні людського капіталу. Освіта і досі оцінюється за внутрішніми критеріями, що не дає змогу проаналізувати іiі якість на всіх рівнях.

Постійне недофінансування сфери освіти в Україні негативно відбивається на іiі

Вісник економіки транспорту і промисловості № 51, 2015 
якості, передусім тому, що знижує мотивацію викладацького складу до творчої та плідної праці.

Недофінансування науково-технічної сфери не сприяє припливу молодих кадрів.

В цілому відсутній зв'язок між якісним навчанням та заробітною платою випускників.

Комерціалізація освіти суттєво звужує можливості доступу до неї дітей 3 малозабезпечених сімей $\mathrm{i}$ до того ж призводить до погіршення якості учнів.

Освітні стандарти та освітні програми не враховують значну диференціацію базового рівня знань та розумових здібностей учнів.

Освітній процес відірваний від сучасних запитів науки та виробництва.

Немає незалежного контролю якості результатів в системі освіти (крім загальносередньої).

Для вирішення зазначених проблем необхідно запровадити наступні заходи.

Формування освітньої складової людського капіталу розглядати як базову складову державної інноваційної політики.

Розробити критерії та показники щодо оцінки ролі освіти у життєдіяльності людини та якості результату освіти.

Вивести фінансування освіти і науки на законодавчо встановлений рівень, в тому числі, за рахунок залучення позабюджетних джерел. На всіх рівнях запровадити індивідуальний підхід та індивідуальні освітні програми, залучити до штату на постійній основі висококваліфікованих психологів для супроводу навчального процесу та профілактики/вирішення академічних та дисциплінарних проблем.

Докорінно змінити роль виробничої практики у навчальному процесі, перетворивши ऑii 3 формальної на реальну складову освіти. На регіональному рівні створити банк даних щодо існуючих проблем (за галузевим розподілом), що слугуватимуть темами відповідних кваліфікаційних робіт та наукових розробок.

Для певних навчальних закладів, що готують фахівців для роботи 3 людьми, де $\epsilon$ дуже високим рівень професійної відповідальності (медики, юристи, соціальні працівники тощо), при прийомі запровадити жорсткий вибір за психологічними, особистісними параметрами.

На всіх рівнях проводити незалежний всебічний контроль якості знань випускників на базі науково-обгрунтованих критеріїв. На підставі цих даних, а також оцінки роботодавців, де працевлаштовуються випускники, скласти рейтинг навчальних закладів.

Комплексне застосування зазначених заходів сприятиме вдосконаленню якості освіти.

Формування якісної освіти забезпечує науково-інтелектуальний потенціал нації, що створює інновацію компоненту розвитку.

Перехід до якісної освіти вимагає перегляду змісту навчання, відмови від застарілих догм, зміни економічних відносин у сфері освіти. Це складний і тривалий процес, де необхідна участь всіх економічних суб'єктів і обов'язково - держави. Але тільки так Україна може встати на шлях інноваційного розвитку.

\section{СПИСОК ЛІТЕРАТУРИ}

1. Яремко Л. А. «Нова економіка» та інноваційний розвиток/ Л. А. Яремко // Маркетинг і менеджмент інновацій. - 2011. №3(1). - С. 25-26.

2. Економіко-правові теоретичні та практичні аспекти переходу економіки України на інноваційну модель розвитку: монографія./ [О. П. Орлюк, О. Б. БутнікСіверський, Н. М. Мироненко та ін.]; наук. ред.. О. Б. Бутнік-Сіверський ; Акад. прав. наук України, Наук.-дослід. ін-т інтелектуальної власності. - Київ: Лазуріт Поліграф, 2010. - 416c.

3. Сімченко Н. О. Чинники розвитку інноваційно орієнтованого суспільства / Н. О. Сімченко, Г. А. Мохонько// Економіка. Управління. Інновації. - 2011. - №2. - С.126131.

4. Длугопольський О. В. Суспільний вектор економіки і публічні фінанси в епоху глобальних трансформацій : монографія / O. В.Длугопольський. Тернопіль : Екон. Думка, THEУ, 2011. - 632c..

5. Грішнова О. А. Людський капітал : формування в системі освіти і професійної підготовки : монографія / О. А. Грішнова. К.: Т-во «Знання», КОО, 2001. - 254c.

6. Зуев А., Интеллектуальный капитал / А. Зуев, Л. Мясникова // Риск - Ресурсы. Информация. Снабжение. Конкуренция (Москва). - 30.12.2002. - 004. - С.4-13. 
7. Цілі розвитку тисячоліття. Україна 2010. Національна доповідь. К, 2010, $107 \mathrm{c}$.

8. Болгова Е. В. Экономическая роль образования : статистический парадокс или проблемы эффективности? / Е. В.Болгова // Креативная экономика. - 2011. - №10(58). C.68-73.
9. Рожко В. І. Безробіття в Україні як показник соціального розвитку країни / В. І.Рожко // Вісник НТУ «ХПІ». Серія : Техн. Прогрес і ефективність виробництва. - Х.: НТУ «ХПІ». - 2013. - №20(993). - С.70-76.

Рецензент д.е.н., професор НУ «ОЮА» Кібік О.М. Експерт редакційної колегії к.е.н., дочент УкрДУЗТ Сухорукова Т.Г.

\title{
УДК 332.8
}

\section{ЕФЕКТИВНА І ГНУЧКА СОЦАЛЬНА ПОЛІТИКА В УМОВАХ ГЛОБАЛІЗАЦЇ̈}

\author{
Пакуліна А.А., к.е.н, доцент (ХНУБА), \\ Пакуліна Г.С., студентка (УкрДУЗТ), \\ Бондарєв С.Е., студент (ХНУБА)
}

\begin{abstract}
Авторами обтрунтовані ініціативи з метою забезпечення ефективної $i$ гнучкої соиіальної політики в умовах глобалізації: для стабілізації рівня життя населення; у контексті розвитку зайнятості; у напрямі розвитку професійного навчання на виробництві; для розвитку робочих місиь; щзодо збереження наявних та створення нових робочих місць; у контексті розвитку соціальної політики щчодо заробітної плати; щчодо розвитку соціальної політики у сфері пенсійного забезпечення; у напрямі поглиблення адресності системи державної сочіальної допомоги.
\end{abstract}

Ключові слова: соціальна політика, глобалізація, соціальний розвиток, інфраструктура, державно-приватне партнерство.

\section{ЭФФЕКТИВНАЯ И ГИБКАЯ СОЦИАЛЬНАЯ ПОЛИТИКА В УСЛОВИЯХ ГЛОБАЛИЗАЦИИ}

\author{
Пакулина А.А., к.э.н, доцент (ХНУСА), \\ Пакулина А.С., студентка (УкрГУЖТ), \\ Бондарев С.Э,. студент (ХНУСА)
}

Авторами обоснованы инициативы с целью обеспечения эффективной и гибкой сочииальной политики в условиях глобализаџии: для стабилизаџии уровня жизни населения; в контексте развития занятости; в направлении развития профессионального обучения на производстве; для развития рабочих мест; для сохранения имеюшихся и создания новых рабочих мест; в контексте развития социальной политики относительно заработной платьл; для совершенствования сочииальой политики в сфере пенсионного обеспечения; в направлении углубления адресности системы государственной социальной помощчи.

Ключевье слова: социальная политика, глобализация, социальное развитие, инфраструктура, государственно-частное партнерство.

(C) Пакуліна А.А., Пакуліна Г.С., Бондарєв C.Е.
Вісник економіки транспорту і промисловості № 51, 2015 